\title{
Complete suppression of haemoglobin A synthesis in haemoglobin D Los Angeles - beta thalassaemia
}

\author{
A. J. MARENGO-ROWE ${ }^{1}$, A. W. MCCRACKEN ${ }^{2}$, AND P. FLANAGAN \\ From the Royal Air Force Institute of Pathology and Tropical Medicine, Halton, Aylesbury
}

SYNOPSIS A family study is reported in which all three siblings were shown to be doubly heterozygous for haemoglobin D Los Angeles and beta thalassaemia, which resulted in a complete suppression of haemoglobin A synthesis. This demonstrates the effects of genetic interaction which occur when ${ }_{\infty}^{\circ}$ the genes for haemoglobin D Los Angeles and beta thalassaemia are both transmitted to the offspring. The importance of family studies in the investigation of haemoglobin abnormalities is stressed.

Complete suppression of haemoglobin A synthesis seems to occur when the genes for haemoglobin D Los Angeles and beta thalassaemia are transmitted to one individual. In the three previous reports of haemoglobin D-thalassaemia, the laboratory results indicated that haemoglobin A was not found (Hynes and Lehmann, 1956; Sukumaran, Sanghvi, and Nazreth, 1960; Ghai, Varma, and Taneja, 1961). In each of these reports, descriptions of peptide mapping were not available, and Hynes and Lehmann could only obtain incomplete family data. Both investigations were carried out in this study of haemoglobin D Los Angeles-beta thalassaemia which occurred in the children of an Indian family from Bombay, who are now resident in Britain.

\section{METHODS}

Standard haematological methods were used (Dacie and Lewis, 1963). Total red and white cell counts were estimated in a Coulter blood cell counter. Serum iron was estimated by the method of Kok and Wild (1960). Haemoglobin $F$ was estimated by the modification by West and McIver (1961) of the method of Singer, Chernoff, and Singer (1951). Solubility tests were carried out as described by Itano (1953). Qualitative and quantitative haemoglobin electrophoresis was performed on cellulose acetate strips (Oxoid) by the method of MarengoRowe (1965); the haemoglobin variant was also demonstrated by paper electrophoresis using Tris buffer at $p \mathrm{H} 8.9$ (Cradock-Watson, Fenton, and Lehmann, 1959). Peptide

'Present addresses: Royal Postgraduate Medical School, Du Cane Road, London, W.12.

'Department of Pathology, University of Texas Medical School at San Antonio, Texas, U.S.A.

Received for publication 4 October 1967. mapping studies were carried out by the M.R.C. Abnormal Haemoglobin Research Unit, Cambridge, as des- $\bigcirc$ cribed by Ingram (1958), Baglioni (1961), and Beale (1966).

\section{CLINICAL AND LABORATORY FINDINGS}

The haemoglobin abnormality was first detected as $\frac{2}{\mathbb{Q}}$ an incidental finding in a girl aged 18, who was examined at Princess Mary's Royal Air Force Hospital, Halton, because of recurring episodes of respiratory infection. No clinical abnormalities were found in the girl, her parents, or her two brothers. There was no reason not to assume true $\frac{8}{0}$ paternity. The details of the haematological in- $\frac{0}{7}$ vestigations are in Table $I$. The serum iron level in the patient was $100 \mu \mathrm{g}$ per $100 \mathrm{ml}$ and the iron- $\delta$ binding capacity $310 \mu \mathrm{g}$ per $100 \mathrm{ml}$.

The father and the three siblings showed at least 의 two of the haematological stigmata of thalassaemia (Malamos, Fessas, and Stamatoyannopoulos, 1962), 으․ namely, alterations in red cell morphology, low mean corpuscular haemoglobin, and increased $\%$ osmotic resistance. Sickling tests were negative and $\tilde{O}$ solubility tests were normal in all members of the $\underset{\omega}{N}$ family. The results of haemoglobin electrophoresis are shown in Figures 1 and 2 and Table II. The father had a normal haemoglobin composition but $a \stackrel{\varnothing}{\varnothing}$ raised level of haemoglobin $A_{2}(5 \%)$. The mother $\stackrel{\infty}{?}$ had haemoglobin $A$ and haemoglobin $D$. The patient 0 and her two brothers had almost entirely haemo- $O$

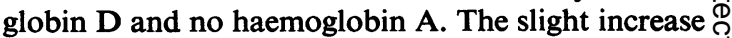
in alkali-resistant haemoglobin $(2.9 \%)$ which was $\overrightarrow{\mathbb{D}}$ present in the father was considered of doubtful significance because of inherent errors in the method 08 
TABLE I

HAEMATOLOGICAL FINDINGS IN THE FAMILY

Age

\begin{tabular}{lllll}
\hline Patient & Brother 1 & Brother 2 & Mother & Father \\
18 & 17 & 13 & 40 & 41
\end{tabular}

Haemoglobin $(\mathrm{g} / 100 \mathrm{ml})$

$\operatorname{RBC}\left(\times 10^{\circ} / \mathrm{cu} \mathrm{mm}\right)$

$\operatorname{PCV}(\%)$

$\operatorname{MCV}(\mathrm{cu} \mu)$

$\mathrm{MCH}(\mu \mu \mathrm{g})$

Reticulocytes (\%)

Platelets $\left(\times 10^{5} / \mathrm{cu} \mathrm{mm}\right)$

Total WBC (per cu mm)

Red cell fragility

(g/100 ml NaC1)

Begins at

Ends at

Peripheral blood

morphology

Serum bilirubin $(\mathrm{mg} / 100 \mathrm{ml})$

$\mathrm{Hb} \mathrm{A}_{2} 5 \%$

$\mathrm{Hb} \mathrm{A}_{2} 2 \%$

$\quad 0 \cdot 45$
$\quad 0 \cdot 20$
Leptocytes,
schistocytes,
moderate aniso-
and poikilo-
cytosis

$1 \cdot 0$

$13 \cdot 8$
$6 \cdot 2$
44
71
22
1
3
10500

0.5

$\quad 0 \cdot 30$
Leptocytes,
schistocytes,
marked aniso-
cytosis

$10 \cdot 5$
$5 \cdot 1$
35
68
21
1
3
10000

$\quad 0.45$
$\quad 0.30$
Leptocytes,
schistocytes,
ovalocytes,
moderate aniso-
cytosis

$1 \cdot 0$

$13 \cdot 1$
$4 \cdot 5$
42
93
29
1
$2 \cdot 1$
6500

0.50
0.30
Normal
appearances

$1 \cdot 4$

$1 \cdot 1$
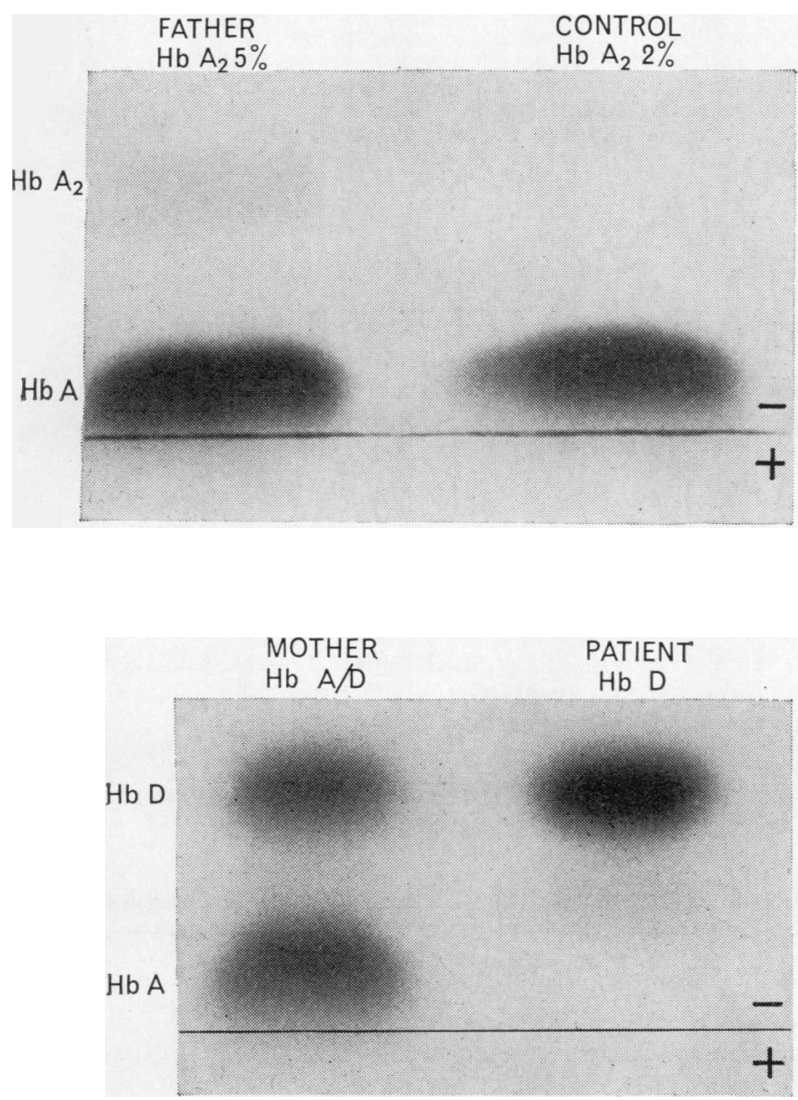

FIGS. 1 and 2. Cellulose acetate electrophoresis in Tris buffer at $\mathrm{pH} 8.9$ of the haemoglobins from the father, mother, and patient.
TABLE II

HAEMOGLOBIN COMPOSITION

Patient Brother 1 Brother 2 Mother Father

\begin{tabular}{lcccrc}
\hline Haemoglobin A (\%) & nil & nil & nil & 73 & 93 \\
Haemoglobin A ( $\%)$ & $<3.0$ & $<3.0$ & $<3.0$ & $<3.0$ & 5.0 \\
Haemoglobin F (\%) & 1.2 & 1.0 & 1.0 & 1.3 & 2.9 \\
Haemoglobin D (\%) & $>95.0$ & $>95.0$ & $>95.0$ & 23.0 & nil
\end{tabular}

of estimation at low levels and because alkaliresistant haemoglobin and haemoglobin $F$ are not necessarily synonymous in adults (Falbe-Hansen, 1961). The haemoglobin variant in the patient was identified as haemoglobin D Los Angeles by peptide mapping.

\section{DISCUSSION}

Beta thalassaemia is the most widespread abnormality of haemoglobin production and its distribution is worldwide (Lehmann and Huntsman, 1966). In this condition the rate of synthesis of the beta chains of the globin molecule is impaired and leads to deficient production of haemoglobin A. The 'excess' of alpha chains present becomes available for combination with delta and/or gamma chains and results in the increased formation of haemoglobin $\mathbf{A}_{2}$ and/or haemoglobin F (Ingram and Stretton, 1959; Malamos et al, 1962). Haemoglobin D Los Angeles (formerly haemoglobin D Punjab) is found principally in Northwest India although there are instances in European populations; this haemoglobin is a variant in which glutamine is substituted for glutamic acid at position 121 in the beta chain (Lehmann and Huntsman, 1966).

In the father the haematological findings and raised haemoglobin $\mathbf{A}_{2}$ level are consistent with beta 
thalassaemia. The mother's blood contained $23 \%$ haemoglobin $\mathrm{D}$, the remainder being mainly haemoglobin A; this is consistent with haemoglobin $\mathrm{D}$ trait (Chernoff, 1958). In the three siblings haemoglobin A was completely lacking; the haemoglobin present was almost entirely haemoglobin $\mathrm{D}$. These findings indicate that all three siblings inherited a D beta gene from the mother and a beta thalassaemia gene from the father. The substitution of $D$ beta chains for normal beta chains in the haemoglobin composition of the three siblings represents genetic interaction between the two inherited abnormalities which in this instance led to a complete suppression of haemoglobin A synthesis.

Since the laboratory findings in haemoglobin Dthalassaemia are little different from those of homozygous haemoglobin $\mathrm{D}$ disease, it is essential to carry out a family study if the true nature of the abnormality is to be determined. It is interesting to note that all three siblings were doubly heterozygous for haemoglobin D and thalassaemia and that none of other possible genetic alternatives occurred.

We are indebted to Professor H. Lehmann and Dr D. Beale for providing the peptide maps and to Air Vice-
Marshal W. P. Stamm for his helpful advice and criticism. We are grateful to $\mathrm{Mr} \mathrm{J}$. Watkin for the photographs and to the Director-General of Medical Services, Royal Air Force, for permission to publish.

\section{REFERENCES}

Baglioni, C. (1961). Biochem. biophys. Acta (Amst.). 48, 392.

Beale, D. (1966). In Man's Haemoglobins, by H. Lehmann and R. G. Huntsman, p. 299. North-Holland Publ. Co., Amsterdam. \&

Chernoff, A. I. (1958). Blood, 13, 116.

Cradock-Watson, J. E., Fenton, J. C. B., and Lehmann, H. (1959). J. clin. Path., 12, 372.

Dacie, J. Y., and Lewis, S. M. (1963). Practical Haematology, 3rd ed. Churchill, London.

Falbe-Hansen, I. (1961). Brit. J. Haemat., 7, 187.
Ghai, O. P., Varma, K. P., and Taneja, P. N. (1961). Indian J. Child Hlth, $10,334$.

Hynes, M., and Lehmann, H. (1956). Brit. med. J., 2, 923.

Ingram, Y. M. (1958). Biochem. biophys. Acta (Amst.), 28, 539.

- and Stretton, A. O. W. (1959). Nature (Lond.), 184, 1903.

Itano, H. A. (1953). Arch. Biochem., 47, 148.

Kok, D'A., and Wild, F. (1960). J. clin. Path., 13, 241.

Lehmann, H., and Huntsman, R. G. (1966). Man's Haemoglobins, p. 201. North-Holland Publ. Co., Amsterdam.

Malamos, B., Fessas, P., and Stamatoyannopoulos, G. (1962). Brit. J. Haemat., 8, 5.

Marengo-Rowe, A. J. (1965). J. clin. Path., 18, 790.

Singer, K., Chernoff, A. I., and Singer, L. (1951). Blood, 6, 413.

Sukumaran, P. K., Sanghvi, L. D., and Nazreth, F. A., (1960). Acta haemat. (Basel), 23, 309.

West, L. N., and McIver, J. E. (1961). Blood, 17, 166.

\section{Reports and Bulletins prepared by the Association of Clinical Biochemists}

The following reports and bulletins are published by the Association of Clinical Biochemists. They may be obtained from The Administrative Office, Association of Clinical Biochemists, 7 Warwick Court, Holborn, London, W.C.1. The prices include postage, but airmail will be charged extra.

\section{SCIENTIFIC REPORTS}

1 Colorimeters with Flow Through Cells. A critical assessment of 4 instruments. 1965. P. M. G. BROUGHTON and C. RILEY. 13s. 6d.

2 Colorimeters. A critical assessment of 5 commercial instruments. 1966. P. M. G. BROUGHTON, C. RILEY, J. G. H. COOK, P. G. SANDERS, and H. BRAUNSBERG. $15 \mathrm{~s}$.

3 Automatic Dispensing Pipettes. An assessment of 35 commercial instruments. 1967. P. M. G. BROUGHTON, A. H. GOWENLOCK, G. M. WIDdowson, and K. A. AHLQUST. 10s.

\section{TECHNICAL BULLETINS}

9 Determination of Urea by AutoAnalyzer. November 1966. RUTH M. HASLAM. 2s. 6d.
10 Filter Fluorimeters. A comparative list of 14 instruments. March 1967. HANNELORE BRAUNSBERG. 5s.

11 Determination of Serum Albumin by AutoAnalyzer using Bromocresol Green. October 1967. B. E. NORTHAM and G. M. WIDDOWSON. 2s. 6d.

12 Control Solutions for Clinical Biochemistry. February 1968. P. M. G. BROUGHTON. 2s. 6 d.

13 An Assessment of the Technicon Type II Sampler Unit. March 1968. B. C. GRAY and G. K. MCGOWAN. 1s. 6 d.

14 Atomic Absorption Spectroscopy. An Outline of its $\stackrel{\mathscr{Q}}{?}$ Principles and a Guide to the Selection of Instruments. May 1968. J. B. DAWSON and P. M. G. BROUGHTON. 4s.

15 A Guide to Automatic Pipettes (2nd edition). June 1968. P. M. G. BROUGHTON. 5s. 